\title{
Determining survival probabilities for specialised neologisms in medical English and French: a diachronic perspective
}

Probabilités de survie de néologismes spécialisés en anglais et en français médical : perspective diachronique

\section{Coralie Schneider}

\section{OpenEdition}

\section{Journals}

\section{Electronic version}

URL: http://journals.openedition.org/asp/5350

DOI: $10.4000 /$ asp. 5350

ISSN: 2108-6354

\section{Publisher}

Groupe d'étude et de recherche en anglais de spécialité

\section{Printed version}

Date of publication: 1 November 2018

Number of pages: 53-76

ISSN: 1246-8185

\section{Electronic reference}

Coralie Schneider, "Determining survival probabilities for specialised neologisms in medical English and French: a diachronic perspective », ASp [Online], 74 | 2018, Online since 01 November 2019, connection on 02 November 2020. URL : http://journals.openedition.org/asp/5350 ; DOI : https:// doi.org/10.4000/asp.5350

This text was automatically generated on 2 November 2020

Tous droits réservés 


\title{
Determining survival probabilities for specialised neologisms in medical English and French: a diachronic perspective
}

\author{
Probabilités de survie de néologismes spécialisés en anglais et en français
}

médical : perspective diachronique

Coralie Schneider

\section{Introduction}

1 A living language is a language whose lexicon is constantly renewed as new scientific discoveries, technical innovations and sociocultural changes occur. The creation of new lexical units, or neologisms, to name these new concepts, enables the speakers within a discourse community to perceive them and to refer to them. Neological creation thus ensures a much needed linguistic continuity to integrate the discoveries, innovations and progress of a society. This is all the more crucial for specialised discourse in which scientific breakthroughs are described Therefore, researchers and domain experts can, by creating specialised neologisms, enrich and renew the lexical variety of English for Specific Purposes that they use within their own scientific community, be it in the field of physics, biology, medicine, or even in a subfield such as the medical domain of rare diseases which is addressed in this paper.

2 Nevertheless, the creation of a new term does not guarantee that the discourse community will harness it. Terms disappear at every stage of their existence, from their time of birth to the time when the concepts they are referring to become obsolete or, when another term is preferred by the discourse community (Bowker \& Hawkins: 2006). 
3 Although it is often considered that neological creation, theoretically, comes as a response to a terminological gap, that a specialised term is governed by the principles of univocity, of mono-referentiality, that it belongs to a specialized domain, and that it fills a lexical gap, thereby ensuring that all communication needs are met (Rondeau 1984: 129-130), these principles may be invalidated in practical experience.

We may observe the terminological abundance and the synonymic variation which develop along with the birth or the disappearance of a term. (Dury \& Picton 2009:

8) $)^{1}$ (my translation)

4 If the principles of univocity and mono-referentiality are eventually to be met, it may, therefore, be inferred that not all created specialised neologisms become established terms. Some will be reused and fully adopted in some specialised discourse communities (thus obliterating the "feeling of novelty"2 toward former neologisms) and eventually enter a specialised dictionary, or at least be used in authoritative publications and students' textbooks, while others will fall into disuse.

5 I have reasons to believe that the degree of vitality of terms is the reflection of scientific progress and strategic terminological choices made by scientific communities. I also think that this degree of vitality of terms can be monitored through a diachronic corpus-based analysis of a representative sample of scientific publications.

6 Indeed, as both general languages and languages for specific purposes constantly evolve, it seems particularly relevant to measure the evolution of the vitality of terms throughout the years. I therefore suggest that the probabilities for a given specialised neologism to integrate a given discourse community are directly linked to a series of criteria, which I chose to name "survival factors", and which need to be monitored over several years.

7 Some of these survival factors are quantitative, such as the frequency of use (from all $^{3}$ specialised and non-specialised sources ${ }^{4}$ ) and the distribution rate. ${ }^{5}$ An upward or a descending curve is a very highly significant marker of the probabilities for a neologism to permanently integrate a specialised language or to fall into disuse. I postulate that the more a neologism is used, the more likely it will be reused by members of the discourse community who have come across it through reading scientific articles or attending scientific congresses. Other factors are qualitative, such as the potential existence of term variants and/or equivalents, the type of neological creation (compositional, metaphorical...), which may, in the case of variation, hinder the survival chances of a given neologism or, in the case of foreign equivalents, support its integration. ${ }^{6}$

8 When considering foreign equivalents, one should keep in mind that, although English is the main scientific lingua franca, well above all other languages, which Swales (1997: 374) describes as the Tyrannosaurus Rex "gobbling up the other denizens of the academic linguistic grazing grounds", efforts are carried out (either institutionally or individually) to create or adapt, in other languages such as French, denominations for scientific concepts that have previously been named in English. I agree with Sager (1990: 80) that primary term formation which occurs when a new concept is being named for the very first time (usually in English) is more spontaneous ${ }^{7}$ than secondary term formation, which consists either in replacing a current denomination for a known concept by another denomination that is considered more appropriate, or in creating a new denomination in another language in which the concept has never been named before (also called foreign equivalent). In other words, while primary term formation is 
motivated by bridging a communicational gap, secondary term formation often results from standardization initiatives in the language the concept was named for the first time or in other languages (and other discourse communities) benefiting from knowledge transfers. It is necessary to bear this in mind when analysing neologisms, as secondary term formation is more likely to be subject to guidelines regarding controlled term formation patterns (ibid.). Therefore, the type of term formation is to be taken into account when analysing the qualitative factors.

9 I chose to verify the relative importance of each survival factor on a couple of neologisms created by experts of the medical subfield of rare diseases, which has been characterized by an abundance of neological creations over the last few decades.

10 I will first present a brief review of the literature in the field of neology and especially regarding what has already been written about neological integration. I then present the method I applied to carry out my analysis, or in other words, a presentation of the corpus characteristics, of the neologism detection methodology and finally of the data collection for each survival factor. The last part of this paper is devoted to presenting the data for two relevant neologisms.

\section{Theoretical framework}

\subsection{Predicting neological survival probabilities}

11 In order to predict neological survival probabilities, both quantitative and qualitative types of factors are to be considered, as they are likely to contribute to the integration of a specialised neologism in a specialised language.

12 Rondeau (1984: 129) and Boissy and Lerat (1989: 44) were the first to suggest an approach based on statistics and therefore, I took into account the criterion of frequency of use and rate distribution.

13 Taking into account frequency of use as a sole criterion could be reductive and could lead to false interpretation, as the number of different sources where a neologism appears also contributes to reach more experts who will in turn be likely to reuse it. A neologism appearing once in ten different publications is more likely to be seen and is likely to have a more significant impact on readers than a neologism appearing ten times in only one publication. Hence, I consider that the distribution rate criterion is crucial in determining the survival probabilities of a neologism.

14 Among the qualitative survival factors, aside from term variation - which weighs rather negatively on the survival probabilities of a neologism, through what could be qualified as a competition for the survival of the fittest among all terminological and neological variants referring to a same concept ${ }^{8}$ - terminological equivalence needs to be taken into account.

15 Terminological equivalence refers to the notion of adapting, at some point in time, a term coined in one original language for use in another language, a target language. Terminological equivalence often results from thorough language planning strategies as well as experts' initiatives when publishing in a different language. I have been led to consider terminological equivalence as a relevant survival factor for neologism when coming upon the definition of "Terminology planning" by Rousseau (2005: 97): 
Field of intervention for terminological planning aimed at describing, modernising or developing terminologies as well as their social dissemination, within one or several languages whose State or any social sector in a position of public authority promotes the use. ${ }^{9}$ (my translation, bold characters added by me)

The "social dissemination of terminologies in one or several languages" seems to be another crucial factor. In other words, on the one hand, a term that is considered worth adapting in one or several other languages (through secondary term formation) is more likely to survive, as the concept it refers to is worth being named and referred to in other languages. Thus, it could be inferred that this concept is particularly relevant, or at least more relevant than a concept that never gives rise to terminological equivalence and whose denomination remains restricted to the language it was coined in. On the other hand, a neologism that benefits from terminological equivalence in other languages also benefits from a higher visibility, and is thus more likely to be reused. Experts are more likely to come across it either in their own language and/or in a more widely spoken language such as English (which is the main scientific vehicular language - as well as the language of reference). As a matter of fact, a term coined in English is more legitimate than a term coined in any other language since English is the Lingua Franca of the international community and therefore researchers are more likely to read literature in English containing that term rather than literature in any other languages.

As far as both term variation and terminological equivalence are concerned, it would be appropriate to apply the aforementioned quantitative factors (frequency of use and distribution rate) in order to assess their respective importance as competitors in their quest for survival (term variants) and as allies (terminological equivalents).

Moreover, if term variation exists in the language a neologism was coined in, term variation is likely to occur in the languages in which the neologism has been adapted into (terminological equivalence). Therefore, the 'foreign allies' may also, similarly, be engaged in a battle for survival.

19 I have reasons to believe that a successful neologism, when becoming an established term in one given language, provides a competitive advantage to the equivalent that has been created through the same pattern (i.e. literal translation) rather than to those that exhibit more formal differences. A preliminary analysis of my corpus led me to assume that if, for a given neologism, a particular creation pattern is preferred and thus more widely disseminated, non-native speaking experts tend to resort to literal translation; they probably feel more familiar when confronted with a literal translation of the neologism than with another equivalent pattern, and they are more likely to reuse the literal translation. However, this hypothesis needs to be verified. Therefore, I also included creation patterns among the qualitative survival factors to be taken into account.

\subsection{Research scope}

20 As, the concepts of "neologisms" and "rare diseases" do not have a universally accepted definition, I am giving the working definitions I adopted for this study.

21 For the purpose of the study, I consider a neologism to be any medical term created in English or in French since 2007. Therefore, medical scientific articles published from 2007 until 2015 have been collected. Methods used to compile the corpus and to detect 
neologisms are presented in the following section. What matters here is to have a compilation of scientific articles over a given time span during which specialised neological creation has taken place.

The second key concept also needs to be defined in order to build a corpus gathering medical literature published on rare diseases only. Medicine is too large a field, therefore I focussed on a sub-field characterized by neological creation, namely, rare diseases. Medical articles dealing specifically with rare diseases were collected. The selection criterion for research articles was determined by the definition of "rare diseases". However, the notion of rare diseases often differs from one continent to another, from one country to another and sometimes even within the borders of a single country. ${ }^{10}$ Therefore, I fine-tuned my hypothesis stating that a disease is rare if its prevalence is below a certain threshold.

The European Union definition for rare diseases states that a rare disease is any disease affecting one person or fewer out of 2000. ${ }^{11} \mathrm{~A}$ similar definition may also be found on the Orphanet platform, ${ }^{12}$ a portal indexing and providing information on every known rare disease. I therefore adopted this definition, and I took into account the list of rare diseases (most of which are listed along with their prevalence) provided by the Orphanet platform when selecting medical articles.

Moreover, I also wished to include articles dealing with diseases that are considered to be rare in the authors' perspective. Thus, I looked for markers or qualifiers proving that the authors considered the diseases to be rare. These markers consisted in adjectives such as "rare" and "ultra-rare" qualifying the disease or pathology which is being written about.

The next section gives an overview of the research protocol applied, the corpus compiled, and the neologisms studied.

\section{Method}

\subsection{Corpus characteristics}

For the purposes of my study, I considered medical neologisms created between 2007 and $2015^{13}$ and used in written communications dealing with rare diseases. Therefore, I built a corpus of texts published exclusively between $2007^{14}$ and 2015. My study is based on short diachrony or brachychrony (Renouf 2002). However according to Guilbert (1971) quoted by Wijnands (1985) and Sablayrolles (2006), it is not possible to theoretically determine a fixed life span for all neologisms. Some are said to last five years, some ten years, others even longer before integrating the specialised language or falling into disuse. Relying on Sablayrolles (2006: 142) who states that neological life span is variable but always measurable by human life span standards and by human memory abilities, I assumed that an eight-year time period was sufficient to provide valuable and reliable data on the evolution of each survival factors for each targeted neologisms. Following Dury and Picton (2009: 36-37), I assumed that the naming of a new concept is followed by an abundance of term variants. Some are possibly no longer neologisms as of today, some are still in the process of being accepted or discarded by the medical community. 
27 A diachronic corpus is all the more relevant when it comes to studying the survival probabilities for a neologism, as rising or falling trend curves can be distinguished for each quantitative survival factor, that is frequency of use, distribution rate for both neologisms and their term variants and equivalents. My corpus was therefore subdivided into eight sub-corpora, one for each year.

As far as qualitative survival factors are concerned, the diachronic corpus also enabled me to assess any evolution in the context in which the neologisms are used. This allowed me to identify any evolution in the definition of neologisms over the time span from 2007 until 2015. It also enabled me to detect the potential variants and/or equivalents created or already existing during this time lapse.

Since I was carrying out a comparative analysis of both French and English medical neologisms, it was important to compile relatively comparable corpora in both languages. I collected slightly more articles in French; however the English corpora are generally larger, as table 0 shows.

Table 0: The corpus

\begin{tabular}{|l|l|l|l|l|l|}
\hline CORPUS & $\begin{array}{l}\text { Number of } \\
\text { Articles }\end{array}$ & $\begin{array}{l}\text { Number of } \\
\text { tokens }\end{array}$ & CORPUS & $\begin{array}{l}\text { Number of } \\
\text { Articles }\end{array}$ & $\begin{array}{l}\text { Number of } \\
\text { tokens }\end{array}$ \\
\hline Corpus_English & 517 & $2,365,996$ & Corpus_French & 536 & $1,176,486$ \\
\hline Corpus_English_2007 & 44 & 228,243 & Corpus_French_2007 & 47 & 79,191 \\
\hline Corpus_English_2008 & 29 & 149,095 & Corpus_French_2008 & 43 & 107,162 \\
\hline Corpus_English_2009 & 29 & 149,856 & Corpus_French_2009 & 57 & 115,815 \\
\hline Corpus_English_2010 & 15 & 98,32 & Corpus_French_2010 & 48 & 107,751 \\
\hline Corpus_English_2011 & 37 & 171,14 & Corpus_French_2011 & 84 & 172,908 \\
\hline Corpus_English_2012 & 21 & 53,881 & Corpus_French_2012 & 56 & 126,242 \\
\hline Corpus_English_2013 & 205 & 953,826 & Corpus_French_2013 & 51 & 106,055 \\
\hline Corpus_English_2014 & 77 & 378,086 & Corpus_French_2014 & 83 & 205,169 \\
\hline Corpus_English_2015 & 60 & 183,549 & Corpus_French_2015 & 67 & 156,193 \\
\hline
\end{tabular}

The corpus was used for term detection only and I broadened my scope to any medical source published on the Internet for a better representativity of the qualitative and quantitative data I intended to collect regarding all above-mentioned survival factors. To achieve this, I used the search engines Google Scholar for specialised publications and Google for non-specialised sources. 


\subsection{Neologism detection}

31 Prior to collecting factors of survival probabilities, I needed to identify a sample of both French and English rare disease-related neologisms within my corpus. After a thorough consideration of different neological extraction methods, I chose, for practical purposes, to resort to a methodology suggested by Pearson (1998) who uses "linguistic signals" or suggested by Cabré and Estopà who evoke "neologicity filters" (2009). Although Pearson (1998: 130) does not mention "neologisms markers" per se, her considerations about "linguistic signals", that is a list of words or expressions such as: "called, known as, “...", the term, etc." co-occurring along with potential terms (or term-candidates) enabling her to extract from a text corpus, a list of term-candidates, were adapted to newly created terms only. This is what may be referred to as "neologism markers".

The "neologicity filters" used are related to the cognitive criterion defined by Rey (1976:14) as occurring when a speaker or a community of speakers perceives a word or a term as new (also referred to as "the feeling of novelty"). These neologisms markers are words, phrases or expressions accompanying neologisms and providing information about them. They provide information about the context; that is whether a concept has recently been invented, whether a noun has recently been created, whether there is a lack of occurrences of the neologism prior a certain date.

I assumed that, when confronted with a specialised neologism, authors and readers alike experience the feeling of neologicity. When introducing a neologism that authors expect readers not to be familiar with, they may most probably introduce it along with one of these neologisms markers previously mentioned. I drew up a non-exhaustive list of neologisms markers which enabled me to detect neologism-candidates.

The first table illustrates my use of Pearson's 'linguistic signals', which I translated into French as I was looking for neologisms in both languages in my bilingual corpus. While some of Pearson's 'linguistic signals' helped detect neologism-candidates (such as the inverted commas, "the term", “called", "known as"), I also added other markers which I found in the immediate context.

Table : Denomination introducing markers

\begin{tabular}{|l|l|}
\hline English & French \\
\hline “..” & «..» \\
\hline the term & le terme \\
\hline the name & le nom \\
\hline the denomination & la dénomination \\
\hline under the name & sous le nom / sous l'appellation \\
\hline mentioned & mentionné \\
\hline a new concept & un nouveau concept \\
\hline
\end{tabular}




\begin{tabular}{|l|l|}
\hline termed / named / called / considered, coined & nommé / baptisé / appelé / considéré \\
\hline the typical & typique / classique \\
\hline
\end{tabular}

The second table introduces time markers, mainly time adverbs, which may indicate a new term creation (for a new concept that had never been named before) or indicators of a change of name (give a concept a more adequate name, for example). These time markers have been used in combination with the denomination-introducing markers above-mentioned.

Table : Time markers

\begin{tabular}{|c|c|c|c|}
\hline \multicolumn{2}{|l|}{ English } & \multicolumn{2}{|l|}{ French } \\
\hline previously... & \multirow{5}{*}{$\begin{array}{l}\text {...named, termed, referred to (as), known } \\
\text { (as), applied to (noun applied to), agreed, } \\
\text { called... }\end{array}$} & préalablement... & \multirow{5}{*}{$\begin{array}{l}\text {...nommé, baptisé, } \\
\text { appelé, connu (sous) }\end{array}$} \\
\hline recently... & & récemment... & \\
\hline formerly... & & & \\
\hline originally, & & à l'origine... & \\
\hline initially... & & initialement... & \\
\hline $\begin{array}{l}\text { first reported } \\
\text { as }\end{array}$ & & & \\
\hline \multicolumn{2}{|c|}{ Preterit use (The authors proposed) } & \multicolumn{2}{|c|}{$\begin{array}{l}\text { Past tense use (Les auteurs ont } \\
\text { proposé) }\end{array}$} \\
\hline
\end{tabular}

The introduction of a specialised neologism may be preceded or followed by a comment by the author so as to justify the necessity to resort to it. The markers in table 3 have either been found in the immediate context of neologisms in my corpus, or are translations of those found in my corpus.

Table : Markers transmitting a comment by the author

\begin{tabular}{|l|l|}
\hline English & French \\
\hline (as) to deserve the term / the name & pour mériter le terme de / le nom de \\
\hline should be renamed / should be preferred & devrait être renommé / devrait être privilégié \\
\hline we proposed XXX be renamed & nous suggérons que XXX soit renommé \\
\hline it should be referred to as a proper name & il devrait y être fait référence via un nom propre \\
\hline so called & appelé à tort, soi-disant \\
\hline
\end{tabular}




\begin{tabular}{|l|l|}
\hline considered as & considéré comme (par d'autres chercheurs) \\
\hline the proposed term & le terme proposé \\
\hline the use of the word / term & l'emploi du mot / du terme \\
\hline
\end{tabular}

37 These markers are particularly interesting, since they are a testimony of the neological production work. The neologisms may or may not have been created by the author of the article, but whether it is the case or not, the marker provides a comment, a gloss on the acceptability of the neologism according to the author (Dury 2012: 86).

Moreover, if a term is new, it is likely that the author does not expect the readers to know what it refers to. A definition, or at least definitional elements, may occur in the immediate context near neologisms in research articles. Therefore definition markers like those in the table below (table 4) may be used to detect neologism-candidates.

Table : Definition markers

\begin{tabular}{|l|l|}
\hline English & French \\
\hline defined as & défini comme \\
\hline described as & décrit comme \\
\hline
\end{tabular}

In table 2, I discussed those time markers that may be indicators of a change of name. A change of name does not necessarily mean that the former name immediately and completely falls into disuse when the new denomination starts being used. Often two or more denominations coexist to refer to one single concept. This is what I referred to as "term variation" in the Introduction. I also hypothesized that term variation may be a factor hindering neological survival by introducing some competition.

It is therefore important to identify the potential existing term variants for each neologism I have detected in my corpus. This is why term variation markers are particularly useful to identify them. I have listed in table 5 the term variation markers I used. The adverb "also" often replaces the time adverbs used to build time markers.

Table : Term variation markers

\begin{tabular}{|l|l|}
\hline English & French \\
\hline also called / named / known (as) & aussi appelé / nommé / connu (comme) \\
\hline can also be termed & peut aussi être nommé \\
\hline called by some authors & appelé par certains auteurs \\
\hline often labeled as & souvent catégorisé comme \\
\hline
\end{tabular}


41 The neologisms markers enabled me to generate a list of around 200 potential English neologisms and 40 potential French neologisms. It is highly probable that such significant discrepancy between the two languages is attributable to the status of English as a lingua franca (Swales 1997), to the fact that primary term formation is more likely to occur in the lingua franca and to the fact that neologisms introducing markers may be more frequently used, in my corpus, when resorting to primary term formation rather than secondary term formation.

It is indeed likely that most discussions regarding the naming of concepts take place in English and that therefore such markers may be more present in English publications than in French publications. Every term identified using the neologisms markers search is, therefore, considered to be a potential neologism.

Most of the neologisms-candidates identified in my corpus are polylexical units. I, thus, need to distinguish actual terms referring to a given concept from explanatory or definitional paraphrases. The existence of determiners such as "a" or "an" prior to a polylexical unit is a good indicator that I am dealing with a term (Pearson 1998: 128).

Due to the relatively small size of the research corpus, I chose to broaden my research scope to all the sources published at some point on the Internet. I therefore carried out a research for each of these potential neologisms, both in Google Scholar and Google in order to track their first appearance. Both of these search engines include a search function by entering the year of publication as a parameter.

45 I have thus been able to detect 38 English neologisms and 31 French neologisms. They all refer to a concept that is specific to the field of rare diseases, and there is no recorded entry for any of them prior to 2007 either in Google Scholar or Google.

For each of these 69 neologisms, I need to collect the data via Google and Google Scholar that enable me to assess the respective weight of each of the survival factors of my hypothesis.

A search for each neologism on both search engines provides me with information on the number of publications (whether specialised such as articles, theses, books, medical courses material, etc. or non-specialised sources such as blog articles, forums, family associations' webpages, etc.) containing at least one occurrence of each of the detected neologisms or of any of their term variants or equivalents.

Each search focusing on each term (whether a neologism, a variant or an equivalent) also provides me with the publication year for each of these publications. For a given year, I am able to know how many specialised and non-specialised sources containing one given term have been published. I may therefore have a good idea of the evolution of both the frequency of use and the distribution rate of all neologisms, their variants and equivalents; and as I am no longer restricted with the starting and ending dates of the corpus, I may also collect data that provide information on the behaviour tendencies ${ }^{15}$ of older variants and equivalents (before 2007). I am, therefore, able to observe the tendencies of each of the neologisms, variants and equivalents' up to today rather than stop in 2015 (which is my corpus' ending date). 


\section{Results and discussion}

To illustrate the survival odds of neologisms over time, we present two examples from our corpora. A French and an English neologism were chosen. Each of them appeared at the beginning of the period covered by the research corpus.

51 Two different neological creation patterns were selected, because they are representative of those that may be found in my sample: compositional and metaphorical creations. The first neologism, "neuro-cardio-facio-cutaneous syndromes", is an umbrella term used to name a family of syndromes that have been classified together. "Aspect en drap froissé", a metaphorical neologism, refers to one of the symptoms of another disease. It describes a symptom of the disease, likening it to a more common daily-life reality.

Table 6 summarizes the characteristics of these two neologisms.

Table 6: Presentation of neologisms

\begin{tabular}{|l|l|l|l|}
\hline Neologism & Year & $\begin{array}{l}\text { Neological creation } \\
\text { pattern }\end{array}$ & Definition \\
\hline $\begin{array}{l}\text { Neuro-cardio-facio- } \\
\text { cutaneous syndromes } \\
\text { (EN) }\end{array}$ & 2008 & Compositional & $\begin{array}{l}\text { Family of hereditary diseases sharing, to } \\
\text { varying degree numerous common } \\
\text { characteristics: } \\
\text { Craniofacial dysmorphia } \\
\text { Growth delay } \\
\text { Mental retardation or learning disabilities } \\
\text { Cardiac malformations } \\
\text { Cutaneous anomalies }\end{array}$ \\
\hline $\begin{array}{l}\text { Aspect en drap froissé } \\
\text { (FR) }\end{array}$ & 2007 & Metaphorical & $\begin{array}{l}\text { Gaucher disease symptom (appearance of the } \\
\text { cytoplasm of a certain type of cell) }\end{array}$ \\
\hline
\end{tabular}

\subsection{Frequency \& distribution}

Figures 1 and 2 show the respective evolution for both quantitative survival factors (frequency of use and distribution rate) for each neologism. Since "aspect en drap froissé" is a hapax legomenon, I did not include its distribution rate. Figures 1 and 2 include all the data available on both Google Scholar and Google. 
Figure 1: Evolution of neologism number 1

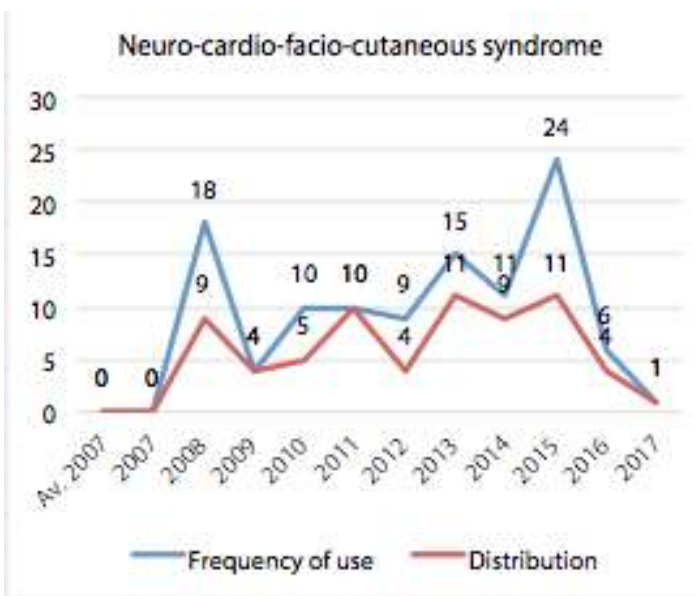

Figure 2: Evolution of neologism number 2

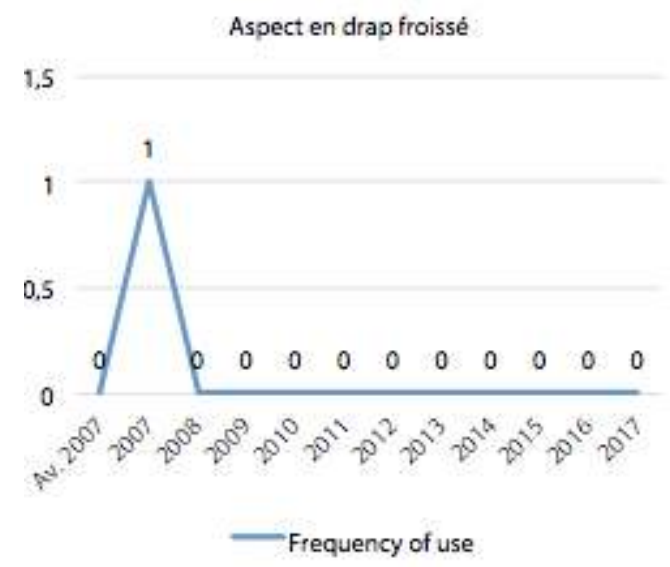

The compositional neologism "neuro-cardio-facio-cutaneous syndrome" is likely to integrate the medical language. It focuses on the organs affected by the disease, and the experts' decision to resort to this term is most probably based on this paradigm. The distribution rate curve is consistent with the frequency of use curve, and it is highly likely that this new umbrella denomination benefits from significant visibility among experts.

On the contrary, the metaphorical neologism "aspect en drap froissé" is a hapax legomenon. It is used to refer to the appearance of a cell that is specific to the Gaucher disease. It dwells on the resemblance between its cytoplasm and a crumpled sheet. Many objects from everyday life can be likened to the cytoplasm found in Gaucher cells. This medical concept has stimulated the creativity and imagination of researchers, thus giving birth to a wide variety of term variants. Generally speaking, medical metaphors may be resorted to when describing the structure of body parts (Salager-Meyer 1990).

\subsection{Variation}

Tables 7 and 8 summarize the term variants found for each neologism. They have all been found to co-occur with the neologisms under study, thanks to term variation markers (see Table 5). 
58 Two of the neologisms detected in my corpus refer to the same concept. The neologism "RASopathies" was observed in the French-language corpus and is a French equivalent as well as an English variant of the English neologism "neuro-cardio-facio-cutaneous syndromes".

Table 7: Variants of neuro-cardio-facio-cutaneous syndromes

\begin{tabular}{|l|}
\hline neuro-cardio-facio-cutaneous syndromes \\
\hline neuro-cardio-facial-cutaneous syndromes \\
\hline neuro-cardio-facious-cutaneous syndromes \\
\hline neuro-cardio-facial-cutaneous disorders \\
\hline neuro-cardio-facio-cutaneous disorders \\
\hline NCFC syndromes \\
\hline NCFCS \\
\hline NCFC disorders \\
\hline NCFC \\
\hline RASopathies \\
\hline
\end{tabular}

Table 8: Variants of aspect en drap froissé

\begin{tabular}{|l|}
\hline bordure d'aspect déchiqueté, froissé \\
\hline aspect de/en papier froissé \\
\hline aspect caractéristique froissé \\
\hline aspect caractéristique à cytoplasme froissé \\
\hline aspect strié ou froissé \\
\hline aspect déchiqueté, froissé \\
\hline aspect caractéristique en papier froissé \\
\hline aspect caractéristique à cytoplasme froissé \\
\hline aspect très feuilleté \\
\hline
\end{tabular}

59 For clarity purposes, I present the most frequent variants. One may note considerable variation on the ending of "fac"* (facio-, facial-, facious-), as well as on the lexical units "syndromes" and "disorders", that seem to be interchangeable. 
60 Figures 3 and 4 respectively show the distribution rate and the frequency of use of the main variants of "neuro-cardio-facio-cutaneous syndromes". High distribution rates may provide more visibility than high frequencies of use combined with low distribution rates, since, if a neologism appears in a greater number of sources, the probabilities that a given reader may come upon it are higher than if the neologism only appears in a smaller number of sources. The number of occurrences in a single article may contribute to increasing the reader's awareness about the neologism. However, for that to happen, the reader needs first to come upon at least one article containing the neologism. With a higher number of articles containing the neologism, the chances of being confronted to it also increases.

Figure 3: Evolution of the distribution rate of the variants of neologism number 1

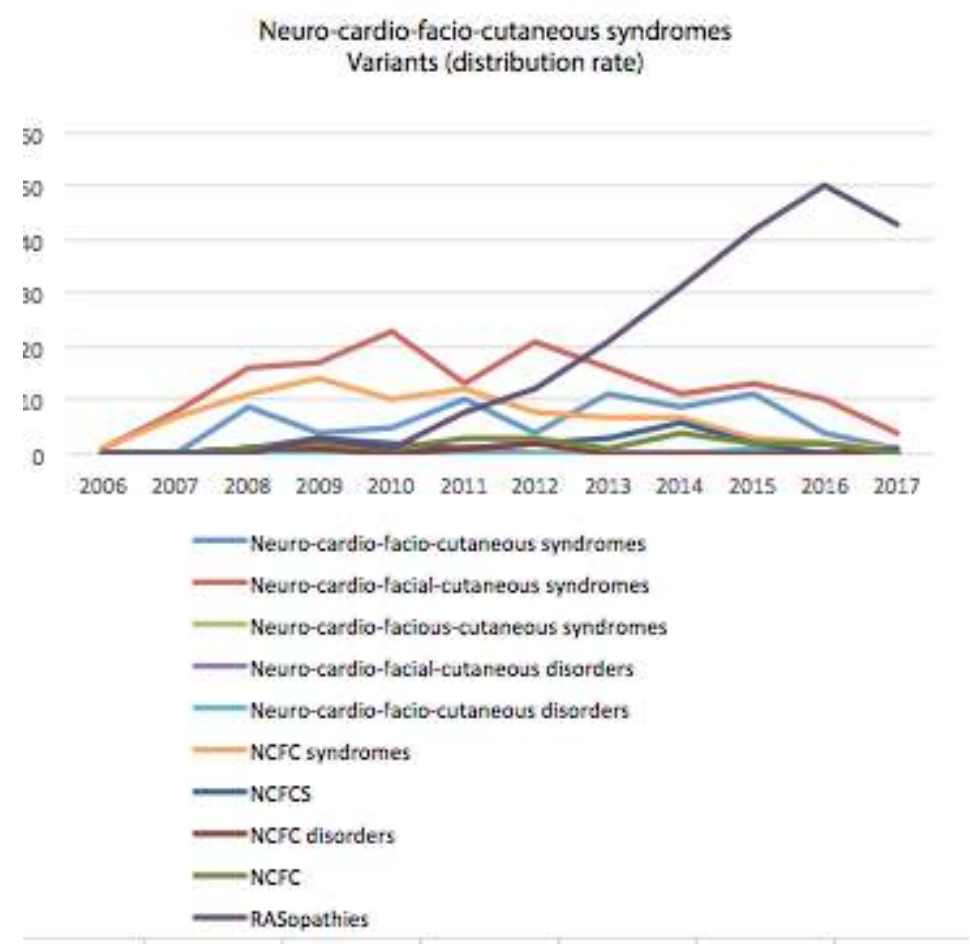


Figure 4: Evolution of the frequency of use of the variants of neologism number 1

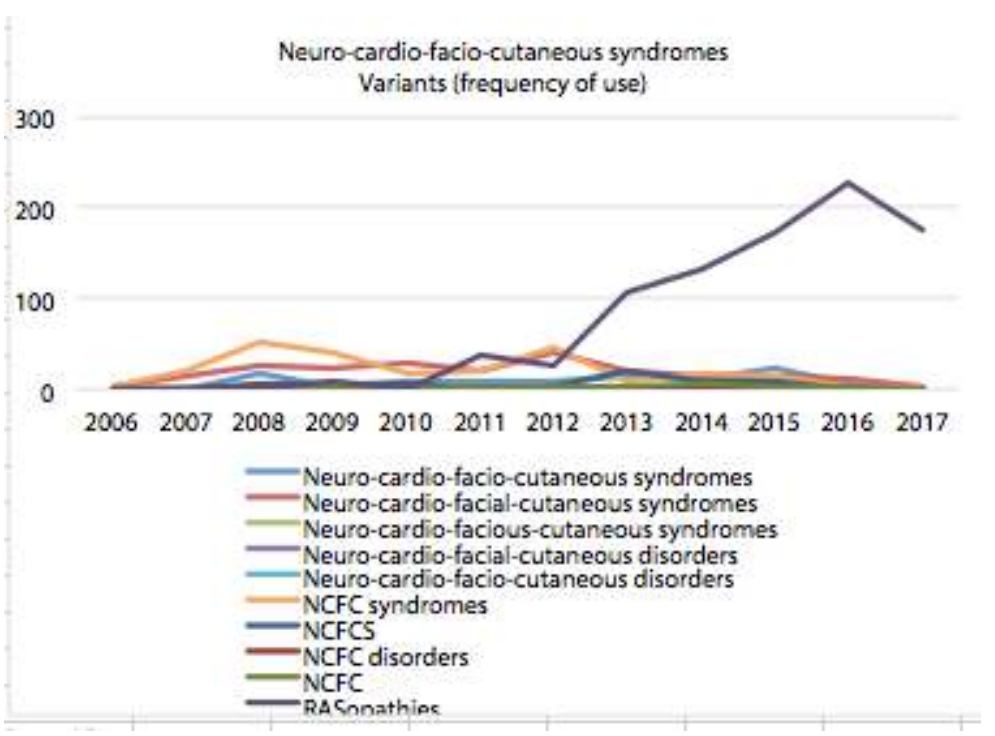

61 The extended term "neuro-cardio-facial-cutaneous syndromes" and the partial acronym "NCFC syndromes" were the most used (in absolute values, all sources combined) and reused by different authors until 2011 when they started to face extremely serious competition from the monolexical neologism created in 2009, "RASopathies"16. "RASopathies" is now much more widely used and therefore enjoys higher visibility among readers. It is also short and thus "NCFC syndromes" loses its comparative advantage based on brevity.

"RASopathies" is also a compositional creation. It combines RAS (which is the denomination of a family of related proteins) with the Greek combining form pathy often used to name diseases. The combining form pathy means "feeling" or "suffering" and therefore the emphasis seems to be laid on the patient's suffering. The neologism "RASopathies" does not focus on the symptoms contrary to its variant "neuro-cardiofacial-cutaneous syndromes". It focuses on the origin of the diseases: a defaulting RAS pathway leading to the synthesis of a dysfunctional type of protein responsible for growth control (and whose symptoms were included in other neological variants). The emphasis is switched to the causes and not to the consequences of this group of diseases, which could also lead researchers to reuse it aside from its shortness.

As far as my second neologism is concerned, "aspect en drap froissé", it is much more difficult to determine which variant is more likely to prevail, as most of its variants are either hapax legomena or have a very low frequency rate. It was more relevant to show the evolution of their frequency of use than their distribution rate.

Many interchangeable adjectival units such as froissé, déchiqueté, strié, feuilleté are often used to create variants. Even though the variant "aspect feuilleté" mainly predominates, it is the adjective froissé that occurs most often as part of a polylexical term (including nouns such as cytoplasme, aspect, papier, papier de soie, drap). I did not enter all of them in Figure 5 , for the sake of clarity again. 
Figure 5: Evolution of the variants of neologism number 2

Aspect en drap froissé

$4 \quad$ Variants (Distribution rate)

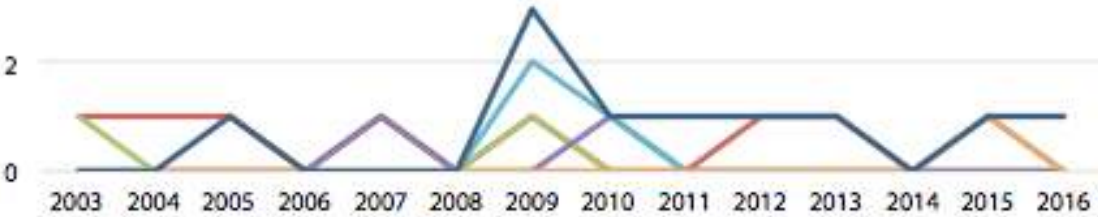

$\begin{array}{llllllllllllll}2003 & 2004 & 2005 & 2006 & 2007 & 2008 & 2009 & 2010 & 2011 & 2012 & 2013 & 2014 & 2015 & 2016\end{array}$

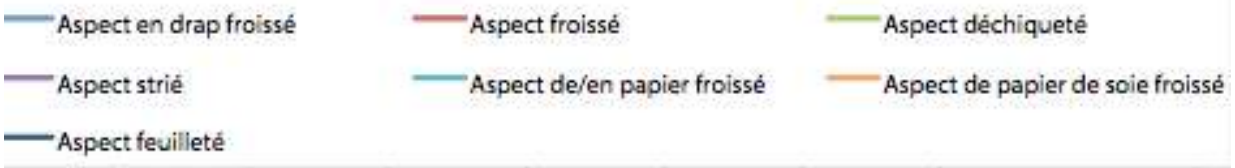

65 As shown in figure 5, there is a high level of formal instability, with the inclusion of words such as "aspect très feuilleté", "aspect caractéristique en papier froissé", with the adjunction of other synonymous or quasi-synonymous adjectives "aspect déchiqueté, froissé comme arraché" or "aspect feuilleté, vacuolisé ou complètement clair". Here, it is not always possible to distinguish between terms and descriptive paraphrases, since some polylexical terms were former descriptive paraphrases that underwent a lexicalisation process. However, given that the concept that needs to be named is not a recent one, given that such formal instability persists and given that there is a profusion of variants ${ }^{17}$ with such low levels of frequency of use, it is arduous to predict which variant is likely to survive. It seems that every author is trying to show lexical inventiveness. It is also possible that a unique denomination is not regarded as essential to describe this particular symptom.

\subsection{Equivalence}

In Table 9, there are far fewer equivalents for "neuro-cardio-facio-cutaneous syndromes". The English neologism whose success can be predicted (neuro-cardio-facial-cutaneous syndromes) does not appear to have been literally translated into French. Its rival "neuro-cardio-facio-cutaneous syndromes", on the other hand, has been literally translated into "syndromes neuro-cardio-facio-cutané". I tend to believe that French-speaking researchers who come across the term "syndromes neuro-cardio-facio-cutané" are more likely, when writing in English, to resort to its literal translation.

However, it is unlikely that most English-speaking researchers may read French medical literature, since medical literature written in English represents the bulk of medical publication worldwide and also, possibly, because a more limited number of English-speaking researchers possess the linguistic knowledge to read French articles. Foreign support to neologism survival may only be from English to a less widely used language. In other words, the existence of English terms probably influence researchers to resort to using their neological equivalents in French, as French-speaking doctors most probably read and publish in both languages. French terms probably have no or a very limited impact on the survival of their English equivalents.

Table 10 only shows a few of the numerous equivalents for "aspect en drap froissé", many of which were introduced decades ago. The plethora of variants found in French to name that concept is also found in English. 
Table 9: Equivalents of neuro-cardio-facio-cutaneous syndromes

\begin{tabular}{|l|}
\hline syndromes neuro-cardio-facio-cutané \\
\hline SNCFC \\
\hline syndromes NCFC \\
\hline RASopathies \\
\hline
\end{tabular}

Table 10: Equivalents of aspect en drap froissé

\begin{tabular}{|l|}
\hline crumpled silk appearance \\
\hline appearance of crumpled silk \\
\hline crumpled tissue paper \\
\hline crinkled paper cytoplasm \\
\hline wrinkled tissue paper appearance \\
\hline appearance of wrinkled tissue paper \\
\hline crinkled tissue paper \\
\hline wrinkled paper appearance \\
\hline appearance of wrinkled paper \\
\hline chicken scratch \\
\hline
\end{tabular}

In Figure 6, one may notice that "syndrome neuro-cardio-facio-cutane" (blue curve) has been facing serious competition with the neologism "RASopathies" (purple curve) since 2013 onwards. The distribution figures for "RASopathies" are not as high in French as in English, but similar tendencies stand out in both languages. If "Rasopathies" has a higher visibility than any of its variants in French since 2013, one may infer that this tendency has benefited from its corresponding English equivalent "Rasopathies" (see Figure 4). 
Figure 6: Evolution of the equivalents of neologism number 1

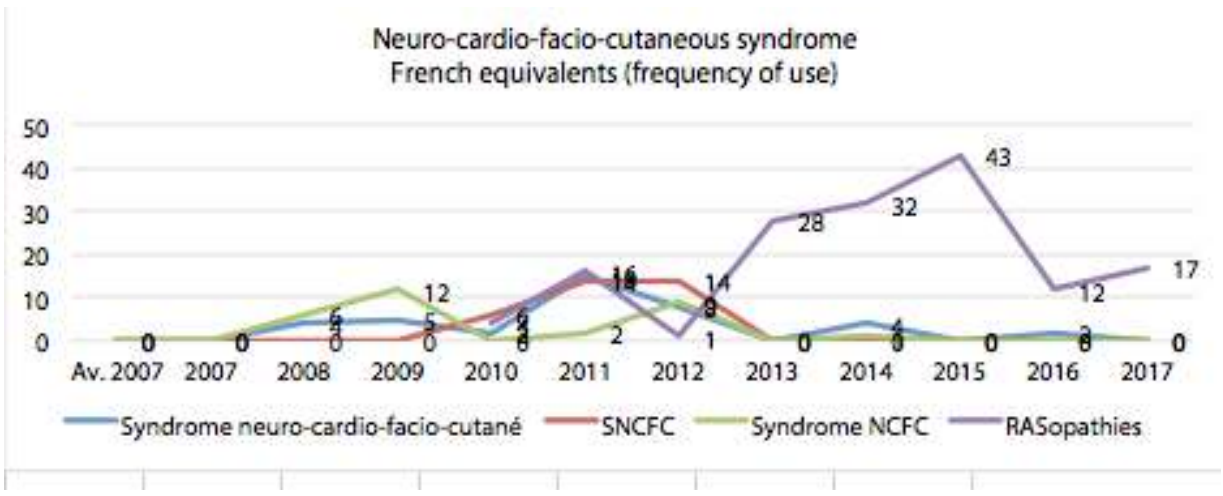

As for the French allies of neologism 2, I have not found any literal equivalent for "aspect en drap froissé" in either Google or Google Scholar search engines. Moreover, Figure 7 clearly shows that for decades, there has been a profusion of English variants to refer to the symptomatic aspect of the cytoplasm of Gaucher cells. For decades also, the frequency of use curve shows that there seems to be no dominant variant. Many are only hapax legomena, and the most successful of them only occurred seven times, which is a very low value if I also take into account the total number of variants chosen by authors in the meantime to refer to the concept. This is at odds with my former claim that instability chiefly concerns new concepts to be named and that eventually a variant takes over, thus bringing terminological stability. For this concept referring to a symptom of a disease, based on the long-term instability of the concept's denomination, it seems that no term is likely, in the near future to prevail to the detriment of others.

There are many more variants than those shown on Figure 7. Some go back to before 1974. For the sake of clarity, I have not entered all of them. However, they have all been created with a metaphor based on daily life. They share a similar pattern: Adj+Noun1(+Noun2). The adjectives and nouns used to create the terms are interchangeable. The descriptive adjectives "crumpled, crinkled, wrinkled", are more or less synonymous and therefore interchangeable. The neological processes at work here are based on an analogy with objects whose appearance is likened to that of Gaucher cells' cytoplasm. These objects (silk, tissue paper, paper...) are therefore also interchangeable. This multiplies the possible combinations to create terms for this concept.

The fact that this concept was originally named in English may account for the very high number of English variants. 
Figure 7: Evolution of the equivalents of neologism number 1

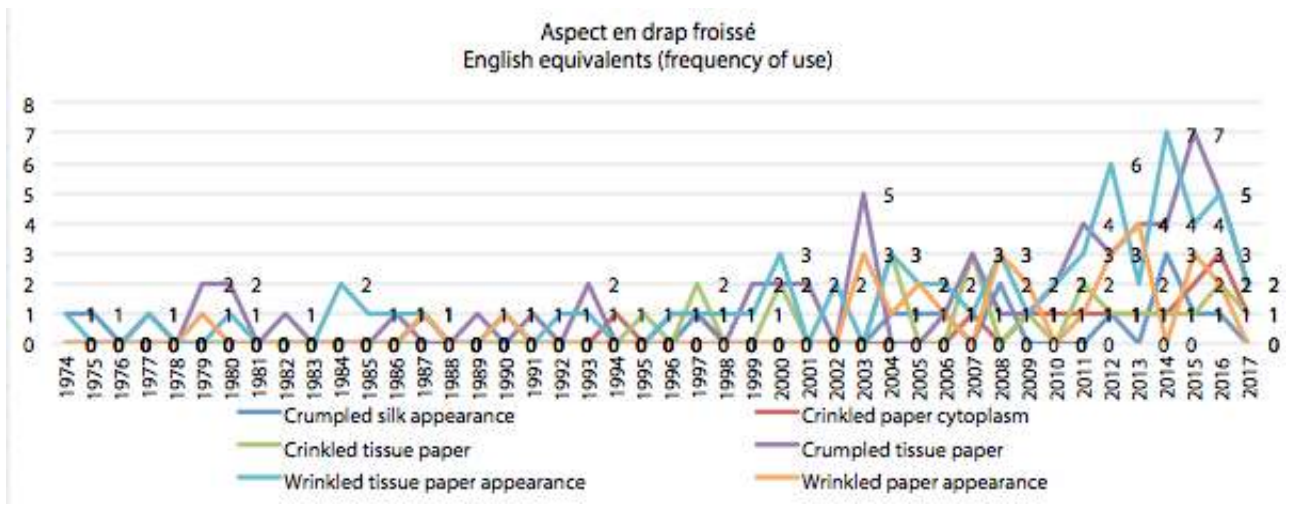

\section{Conclusion}

The analysis presented above allows me to draw some promising conclusions regarding neological variation and creation patterns, which will need to be further investigated.

I chose to illustrate my approach by selecting and showing the data collected for two neologisms, representative of two different types, which I had previously identified in my research corpus. One of them (neuro-cardio-facio-cutaneous syndromes) is an umbrella term used as a denomination for a family of rare diseases. It was created in 2008 by associating the names of the organs affected by the diseases. This neological process based on composition enables anyone familiar with medicine to obtain valuable information about the disorders.

The second neologism (aspect en drap froissé) was created the year before, and it refers to the aspect of the cytoplasm of a certain type of cells which are present in the body of patients with Gaucher disease. It is a metaphorical creation, in which the emphasis is based on the analogy with a daily-life object.

Both neologisms display very different evolution patterns. Whether the emphasis is laid on their frequency of use, or on their distribution rate, or even on the relative importance of both their competitors (variants) or their foreign allies (equivalents), their evolution patterns differ greatly.

Based on these new results, I tend to believe that formal instability may not always be specific to the neological creation time span. On the contrary, as far as "aspect en drap froissé" is concerned, term variation, whether in English or in French, goes back many years. It is highly likely that the term variation will remain in the future. The evidence presented here strongly suggests that no common, unique and standardised denomination will emerge to name this particular symptom of Gaucher disease.

One may gather that while sharing a common denomination for all diseases, pathologies and syndromes is of paramount importance, sharing a common denomination to refer to their symptoms (such as "aspect en drap froissé") may not always be so necessary. These first results have also prompted me to reflect on further questions. Is there a specific type of neological creation according to the type of concept to be named (diseases vs. symptoms for example)? The Council for International Organisations of Medical Sciences (CIOMS) and the WHO (World Health Organization) requires new names to be descriptive ${ }^{18}$ (thus often leading to the creation 
of compositional terms) but nothing is said about naming symptoms or new treatments.

As far as "neuro-cardio-facio-cutaneous syndromes" is concerned, one of its variants and equivalents $^{19}$ (RASopathies) seems to triumph over all its other term variants and equivalents, as shown by the distribution rate and the frequency of use tables (Figures 3, 4 and 6), thus increasing its chances of integration in both the French and English medical discourse. ${ }^{20}$ In this case, it is highly likely that one term only will remain. It is interesting to note the switch of emphasis, in 2013, from the organs affected by the disease to the causes of the disease (a deficient RAS protein pathway leading to the synthesis of deficient cells). This may have been a well-thought out decision made among experts. It is interesting to note that both variants perfectly abide by the rules of a general trend that consist in coining denominations that are as precise as possible, thus resorting to "orthonyms" - term coined for medical terms by Turnpenny \& Smith (2003) - that provide information on the disease such as its causes, its main symptoms or the organs affected (Faure 2017: 72).

I endeavoured to verify whether neological creation patterns and concept types play a role in the permanence of formal variation. My research has also raised new questions which I intend to concentrate on. Is there a potential influence of variants and equivalents appearing in publications listed by authors in their bibliographies, that spur them on to either reuse them or use their literally-translated equivalent in French? I also strongly believe that the location of a neologism within a publication has an impact on its visibility. Neologisms appearing in titles, abstracts, keyword lists, introductions and conclusions will have a more significant impact on readers than neologisms only appearing in the body of the article. I would like to devote some of my research to this in order to further investigate the comparative weight of each of the criteria I defined for neological survival.

\section{BIBLIOGRAPHY}

BOISSY, Jacques \& Pierre LERAT. 1989. “La néographie francophone”. L'information grammaticale 42, 44-48.

BOWKER, Lynne \& Shane HAWKINS. 2006. "Variation in the organization of medical terms. Exploring some motivations for term choice". Terminology 12/1, 79-110.

CABRÉ, Teresa \& Rosa ESTOPÀ, 2009. “Paraules Noves”. $1^{\text {st }}$ ed. Barcelone: Universitat Pompeu Fabra. DAVIES, Kay \& Anthony WYNSHAW-BORIS. 2009. "Human Genetics: Conceptual and practical advances in the post-genome era". Current Opinion in Genetics \& Development 19/3, 193-195.

DURY, Pascaline. 2012. "Le sentiment d'un besoin néologique chez l'expert pour remplacer un terme à connotation péjorative. Quelques exemples tirés du domaine medical”. Neologica 6, 81-93.

DURY, Pascaline \& Aurélie PICTON. 2009. “Terminologie et diachronie : vers une réconciliation théorique et méthodologique ?". Revue française de linguistique appliquée 14/2, 31-41. 
FAURE, Pascaline. 2017. "De Mexican flu à A(H1N1)pdm09 : les efforts de normalisation de l'OMS pour la dénomination des nouvelles maladies infectieuses humaines". ASp 72, 69-81.

PEARSON, Jennifer. 1998. “Terms in context”. Studies in Corpus Linguistics. Dublin: John Benjamins Publishing Company.

RENOUF, Antoinette. 2002. "The time dimension in modern English corpus linguistics". In Kettermann, B. \& G. Marko (eds.), Teaching and Learning by Doing Corpus Analysis. Language and Computers, Graz, 19-24 July 2000, 27-41.

REY, Alain. 1976. “Néologisme : un pseudo-concept ?". Cahiers de lexicologie 28, 3-17.

RICHTER, Trevor et al. 2015. "Rare Disease Terminology and Definitions. A Systematic Global Review: Report of the ISPOR Rare Disease Special Interest Group". Value in Health 18, 906-914. RONDEAU, Guy. 1984. Introduction à la terminologie. Chicoutimi, Québec: G. Morin.

ROUSSEAU, Jean-Louis. 2005. “Terminologie et aménagement des langues”. Langages157, La terminologie : nature et enjeux, 93-102.

SABLAYRolles, Jean-François. 2006. “Terminologie de la néologie : lacunes, flottements et troppleins". Syntaxe et sémantique 7, Presses universitaires de Caen, 79-90.

SAGER, Juan Carlos. 1990. A Practical Course in Terminology Processing. Amsterdam/Philadelphia: John Benjamins.

SALAGER-MEYER, Françoise. 1990. "Metaphors in medical English prose: A comparative study with French and Spanish". English for Specific Purposes 9/2, 145-159.

SWALES, John. 1997. “English as Tyrannosaurus Rex”. World Englishes 16/3, 373-382.

TIDYMAN, William \& Katherine RAUEN. 2009. “The RASopathies: developmental syndromes of Ras/ MAPK pathway dysregulation". Current Opinion in Genetics \& Development 19/3, 230-236.

TURNPENNY, Peter \& Ron SMITH. 2003. “Of eponyms, acronyms and ... orthonyms ». Nature Reviews Genetics 4, 152-156.

WHO. 2015. "Best practices for the naming of new human infectious diseases". Retrieved from <http://apps.who.int/iris/bitstream/10665/163636/1/WHO_HSE_FOS_15.1_eng.pdf> on $25 / 05 / 2018$.

WIJNANDS, Paul. 1985. "Pour une redéfinition du néologisme lexicographique". La Banque des mots 29, 13-24.

\section{NOTES}

1. "On peut aussi observer le foisonnement terminologique et la variation synonymique qui accompagnent souvent l'apparition et la disparition d'un terme."

2. Alain Rey (1976: 14) introduced the "feeling of novelty" strongly related to the concept of neologism and especially specified that this feeling has to be commonly shared within a linguistic community.

3. By frequency of use, I mean the total number of occurrences for a neologism within a discourse community (here the medical community).

4. By specialised sources, I refer to all research papers, doctoral dissertations, medical books and students' textbooks which are mainly found on Google Scholar but may also appear on Google, 
while by non-specialised sources, I mean all blogs, patients' associations' webpages, forums and any sources of medical popularization aimed at the general public.

5. By distribution rate, I mean the total number of different sources, either specialised or not, in which a given neologism (or variant or foreign equivalent) occur at least once. Distribution rate is a quantitative measure. However, further attention could be given to characterizing the sources (scientific papers or popularization articles, high or low impact factor journals...) in future research.

6. One may argue that the existence of a foreign equivalent is a further guarantee that the concept behind the denomination is relevant to the medical community. Therefore it is unlikely that the neologism should disappear since the concept it refers to is deemed relevant and, thus, keeps needing a name.

7. Primary term formation occurs simultaneously with concept formation. It is monolingual and it tends to be spontaneous although there may be some rules for term formation in the frame of specific scientific nomenclatures (e.g. chemical nomenclature or binomial nomenclature for Zoology and Botany).

8. When facing several denominations for a given concept, specialists will select and reuse the denomination they consider the most appropriate based on pragmatic criteria among which one may infer: degree of familiarity of the specialist with the selected denomination, length of the denomination, context of creation and/or appearance of the denomination (prestigious journals, internationally recognised authors at the origin of the denomination...).

9. "Domaine d'intervention de l'aménagement terminologique visant la description, la modernisation ou le développement des terminologies, leur diffusion sociale, dans une ou plusieurs langues dont l'État ou un secteur social faisant autorité préconise l'usage."

10. Trevor Richter et al. (2015) count no less than 296 definitions from over a thousand organizations. Most of them "explicitly or implicitly included a prevalence threshold (172 of 296 definitions [58\%])."

11. Definition by the Centre des Liaisons Européennes et Internationales de Sécurite Sociale. Retrieved from <http://www.cleiss.fr/particuliers/venir/soins/ue/maladies-rares.html> on 22/04/2018.

12. Orphanet was created on the initiative of the French National Institute of Health and Medical Research (INSERM) and is regularly updated by a consortium of medical research organizations from 35 countries. Retrieved from <http://www.orpha.net/consor/cgi-bin/ Education_AboutRareDiseases.php?lng=EN> on 22/04/2018.

13. I have been able to identify the author or authors who created a neologism and the paper in which it appeared for the first time thanks to the denomination introducing markers (see Table 1) and the author's comments about the neologism (see Table 3). Added to this the fact that there are no previous recorded occurrence of the neologisms in any medical journals, theses or any other publications available via ScienceDirect, Pubmed, Google and Google Scholar and that other authors refer to the identified author or authors and paper when mentioning the neologism in later papers.

14. The decision to start my corpus in 2007 is a very pragmatic one. Most English and Frenchspeaking medical journals started to systematically upload articles online as from 2007. I started collecting medical articles for my corpus in 2015.

15. By "behaviour tendencies", I mean frequency of use, distribution rate and everything that I defined under the denomination survival factors.

16. I have been fortunate enough to witness the birth of the neologism RASopathies by Tidyman \& Rauen (2009). The neologism was introduced between brackets. Davies \& Wynshaw-Boris (2009: 194) confirm this paternity: "They [Tidyman \& Rauen (2009)] have termed this group of disorders 'RASopathies'." 
17. These variants seem to be engaged in different stages of the terminologisation process. Some are still apparently closer to being descriptive paraphrases while others share more terminological characteristics (they have a determiner "a" or "an", they appear to be rather fixed polylexical units).

18. World Health Organization Best Practices for the Naming of New Human Infectious Diseases. Retrieved from <http://apps.who.int/iris/bitstream/handle/10665/163636/ WHO_HSE_FOS_15.1_eng.pdf?sequence=1> on 25/05/2018.

19. The term is identical in English and French.

20. I should also mention that most of the French-speaking publications I collected referred to English-speaking publications containing the neologism which had been literally translated in these French-speaking publications. Thus, I should take into account the weight of terms used in publications constituting the bibliography.

\section{ABSTRACTS}

This paper aims to show that the probabilities for a specialised neologism to become an established term are linked to a series of quantitative (frequency of use, distribution rate) and qualitative (term variation and equivalence) factors. Moreover, since, for a given neologism, both the frequency of use and the distribution rate, on the one hand, and the very existence of variants and equivalents, on the other hand, generally differ through the years, a diachronic study is particularly relevant. The literature around the notion of specialised neologism will first be reviewed in order to determine my research hypothesis and the purpose of my analysis. Then, I describe the methodology used to compile a corpus in the medical field of rare diseases and to detect neologisms. Finally, the last section is devoted to analysing, for two neologisms, the data collected for each factor which I assume to be relevant for them to become established terms in this specific discourse community.

Cet article a pour objectif de démontrer que les probabilités de survie d'un néologisme spécialisé sont corrélées à des facteurs d'ordre quantitatif (nombre d'occurrences, taux de distribution) et qualitatif (variation, équivalence terminologique) et qu'il est nécessaire d'envisager leur étude en diachronie. En effet, le nombre d'occurrences d'un néologisme ou le nombre de publications dans lequel il apparaît varie généralement d'année en année. De même, ses variantes et ses équivalents peuvent apparaître ou disparaître au fil des ans. Nous présentons d'abord un bref état de l'art de la notion de néologisme spécialisé duquel nous dérivons notre hypothèse de recherche et le cadre de notre analyse. Puis, nous présentons la méthodologie adoptée pour la constitution d'un corpus spécialisé dans les maladies rares et pour la détection des néologismes. Enfin, la dernière partie est consacrée à l'analyse, pour deux néologismes, des données recueillies pour chacun des facteurs que nous supposons déterminants dans l'intégration du néologisme à la langue de cette communauté de discours.

\section{INDEX}

Mots-clés: anglais médical, diachronie, néologisme

Keywords: diachronic ESP, medical English, neologism 


\section{AUTHOR}

\section{CORALIE SCHNEIDER}

Coralie Schneider is an alumna from ENS Cachan. She is currently preparing a doctoral thesis in both Language Sciences and Anglophone Studies, with joint supervision by the department of Intercultural Studies and Applied Linguistics (EILA) from Paris Diderot University (France) and the IULATERM Research Group from Pompeu Fabra University (Spain). Her research focuses on specialised neology in the medical field of rare diseases. cschneid@eila.univ-paris-diderot.fr 